\title{
mELIITAS
}

36.1 .2020 [67-97]

\section{TATAPAN MEDUSA DAN OKULARSENTRISME: BUDAYA VISUAL DAN PERSOALAN SINEMA KONTEMPORER}

\section{Haryo Tejo Bawono}

\begin{abstract}
:
This article presents some fundamental matters in visual culture. Philosophy has been grappling with important issues of image and ocularcentrism. These matters have shaped and brought impacts on the world's visual culture. On the one hand, an image with all its possible interpretations today tends to be captured as an object and not so much as something that is at the same time plural and moving. On the other hand, people's way of seeing tends to be blurred by the ocularcentrism. This might be a crucial problem that brings significant implications on one of the most important aspects of human life, that is, art activity, and particularly on cinema. The author of this article invites the readers to be aware of the negative inclinations around the issues of image and ocularcentrism. Some of the important challenges in the cinematic world are how people continually reformulate their experience of an image and how the ocularcentrism character in our visual culture can be positioned in the heart of the matter. In an effort to respond to these challenges, one can approach philosophy in a different way in order to refresh his or her way of seeing that might have been tiresome and cloudy.
\end{abstract}

Keywords:

image • ocularcentrism • archeiropoetia • idolatry • iconic-turn • cinema • movingness 


\section{Pengantar}

Pada Oktober 2019 dunia perfilman dihebohkan oleh pernyataan seorang sutradara yang mumpuni karena pengalamannya di dunia perfilman dan karya-karya sinematik yang tidak perlu lagi diragukan. Martin Scorsese, dalam sebuah sesi wawancara dengan Empire Magazine, memberikan sebuah jawaban yang terlalu jujur atas pertanyaan mengenai film-film MCU (Marvel Cinematic Universe). Ia mengatakan, “... [film-film MCU] itu semua bukanlah sinema..... [melainkan] sebuah taman hiburan (theme park)."1 Di desa global seperti sekarang ini, tidak dibutuhkan lebih dari hitungan hari, muncul tanggapan-tanggapan atas pernyataan Scorsese tersebut. Ada yang menyetujui dan banyak yang mengkritik pernyataan Scorsese. Di antara mereka yang kurang setuju, adalah para sutradara yang terlibat dalam waralaba MCU. James Gunn dan Joss Whedon memberikan pernyataan di akun Twitter mereka yang kurang lebih menyesalkan pernyataan Scrosese.

Scorsese akhirnya menjelaskan secara lebih detail alasan mengapa membuat pernyataan semacam itu, dalam sebuah artikel yang dimuat dalam kolom opini di The New York Times. ${ }^{2}$ Dalam artikel itu ia menjelaskan bahwa film adalah sebentuk seni yang, berdasarkan pengalaman sinematik sepanjang hidupnya, seharusnya mampu menghadirkan pengalaman yang tidak terduga (unexpected) dan penuh dengan pertaruhan (risk). Hal-hal ini tidak ditemukannya di film-film superbero $M C U$ dan juga kebanyakan film saat ini. Dalam artikel ini juga ia mengkritik tabiat 'waralaba' filmfilm modern yang secara tidak langsung menyeragamkan selera sinematik masyarakat, dan juga sistem ekonomi di dunia perfilman saat ini, yang dinilainya cukup brutal dan tidak ramah terhadap seni (dalam bentuk film). ${ }^{3}$ Ada banyak pro dan kontra atas apa yang diungkapkan Scorsese dalam opini tersebut. Umumnya, pihak yang berkeberatan atas opini Scrosese mempertanyakan "siapa yang memiliki kualifikasi untuk memutuskan apa yang disebut sebagai 'sinema'?" ", namun tanpa masuk ke dalam persoalan lebih mendasar dari apa yang disampaikan Scorsese.

Artikel ini tidak hendak masuk ke dalam ranah pro dan kontra atas opini Scorsese tersebut, namun lebih melihat polemik ini sebagai sebuah kesempatan yang unik dan berharga untuk melihat lebih dalam dan luas pengalaman sinematik kontemporer kini. Film adalah suatu fenomena 
yang menakjubkan, yang bahkan memiliki sebuah 'keberlebihan' bila dibandingkan dengan karya seni lain, dan karenanya senantiasa merangsang untuk dikaji. ${ }^{5}$ Kajian tentang film sudah ada bahkan sejak apa yang disebut sebagai pinhole camera \& camera obscura tercipta pada 1021. Sejalan dengan perkembangan jenis-jenis film (avant-garde, cinema-verite, dan lainlain), lahirlah banyak teori tentang film, mulai dari Teori New Art, Teori Kognitif, dan seterusnya. Berbagai refleksi filosofis atas film itu seakanseakan berseberangan, bahkan bertabrakan. Para pemikirnya tampaknya memiliki jawaban berbeda-beda atas pertanyaan yang sama: "Apa itu film?", namun mereka memiliki sebuah persamaan, yaitu mengenai pentingnya pertanyaan "Apa itu film?”.

Artikel ini hendak menambah kazanah refleksi tentang apa itu film dengan melihat perjalanan perkembangan film-film kontemporer dan memperlihatkan bahaya-bahaya terselubung dalam peristiwa sinema kontemporer, agar kompleksitas pengalaman nyata keseharian bisa bertemu dengan kreativitas canggih dunia perfilman. Ini adalah sebuah tawaran yang berfokus pada dua tema. Pertama, imaji (image), karena film pada pengertiannya yang paling minimum dan mendasar adalah sebuah imaji-beranjak (moving-image). Kedua, kapasitas seseorang untuk sampai pada imaji-beranjak itu, yakni caranya melihat. Jean Epstein merumuskan keterkaitan dua hal ini sebagai berikut.

"Meskipun penglihatan $(s i g h t)$ sudah dihargai oleh banyak orang sebagai indra yang paling berkembang, dan meskipun sudut pandang intelek dan adat istiadat kita adalah visual, namun tetap saja tidak pernah ada proses emosi yang begitu homogen, begitu eksklusif optis (optical) seperti sinema. Sungguh, sinema menciptakan sebuah sistem kesadaran tertentu yang terbatas hanya pada satu indra."

Bukan hanya Epstein yang memiliki pemikiran semacam ini. Germaine Dulac menulis pada 1925 tentang esensi sinema. Ia mengatakan, "Bukankah seharusnya sinema, yang adalah sebuah seni penglihatan (vision), sebagaimana musik adalah seni pendengaran (bearing).... menuntun kita menuju ide visual yang terdiri dari gerakan dan kehidupan, menuju konsepsi tentang sebuah seni mata (an art of the eye)." ${ }^{\prime 7}$ Hampir empat puluh tahun kemudian, Stan Brakhage menulis karya teoretis tentang sinema yang kurang lebih sama, ketika mengatakan, "Ada sebuah pencarian pengetahuan yang asing bagi bahasa dan didasarkan pada komunikasi 
visual, yang menuntut sebuah pengembangan pikiran optik, dan sangat bergantung pada—dalam arti katanya yang asli dan terdalam—-persepsi." 8 Berbagai keterkaitan antara imaji dan imaji-beranjak yang dirumuskan di atas itu hendak digali lebih mendalam di sini.

\section{Sebuah Archeiropoieta}

Ada peristiwa menarik pada 18 Juli 1689 di Lagny, sebuah kota di Perancis. Petir menyambar Gereja Santo Saverius. Jejak petir tidak hanya tampak pada kaca dan dinding gereja itu, tetapi juga pada sebuah Missale (Buku Misa) yang terbuka lebar di atas altar. Saat proses pembersihan berlangsung, ada sesuatu yang tidak biasa di bawah Missale yang gosong itu: sebuah guratan garis yang jelas di pala (pallium-kain putih) yang menjadi alas Missale itu, yang bertuliskan, Hoc est corpus meum ("Inilah Tubuh-Ku"). Reaksi spontan masyarakat pada saat itu adalah bahwa peristiwa itu adalah sebuah tanda keajaiban. Namun, penjelasan yang ilmiah datang dari seorang imam yang adalah juga seorang ilmuwan, Pierre Lanny, yang memang dipanggil untuk menyelidiki peristiwa itu. Ia menyimpulkan bahwa tulisan yang tercetak di Palla itu adalah efek sambaran petir pada bagian Missale yang terbuka, dan fakta bahwa dari sekian banyak kata-kata yang ada pada halaman yang terbuka itu hanya pada bagian Hoc est corpus meum yang tercetak bisa dijelaskan dengan uraian penggunaan warna dan bagaimana warna dihasilkan untuk sebuah buku di masa itu. ${ }^{9}$ Apakah penjelasan Lanny mencukupi untuk semua pertanyaan di sekitar peristiwa itu, bukan sesuatu yang menarik. Yang menarik adalah: peristiwa itu sedikit banyak membuka celah tentang sebuah sisi yang saat ini mungkin terlupakan dari apa yang biasa disebut sebagai imaji (image): sebuah archeiropoetia, sesuatu yang tercipta bukan oleh tangan manusia.

Dari sekian banyak hamparan imaji, tema ini akan ditelaah dengan imaji-imaji yang dihadirkan dalam tindakan berkesenian (aesthetics). Bila secara sederhana diikuti pembagian seni dari Gotthold E. Lessing menjadi dua bagian, time-based art dan space-based art, ${ }^{10}$ di sini didalami persoalan lewat space-based art, dan secara khusus dari pintu masuk fotografi. Dalam hal ini, bukan karena secara harafiah kata "fotografi" berarti "tulisan-cahaya" (light-writing), atau karena hampir setiap orang memiliki tools dan melakukan kegiatan ini (dengan kamera saku, telpon seluler), 
tetapi karena dibanding seni-seni lain, fotografi sering dianggap sebagai rekaman mekanis (a mechanical record) atau sebagai art-machine, sebuah machine-nation yang dipelesetkan menjadi machination ('intrik', "akal bulus", 'persengkongkolan'), sebentuk otomatisme. ${ }^{11}$ Istilah-istilah itu mengarah pada tuduhan "karakter pasif" fotografi ketika disandingkan dengan seniseni lain. Sebagaimana diamati oleh Rudolf Arheim,
"Apa yang aneh (uncanny) tentang fotografi adalah bahwa gambar tercipta saat seseorang menekan, tanpa sebelumnya terlibat dengan cara apapun, tombol shutter pada mesin kecil. Baik tangan maupun mata tidak perlu melakukan apapun lebih jauh. Karena peran yang dimainkan peralatan (apparatus) itu tampaknya begitu besar, dan yang dimainkan oleh manusia begitu kecil, orang ragu-ragu menyebut produk semacam itu sebagai 'foto', jika dengan istilah itu orang memahaminya sebagai sesuatu yang diciptakan oleh manusia." 12

Emmanuel Santini, dua abad setelah peristiwa petir di Gereja Santo Saverius, Lagny, menulis sebuah artikel di majalah sains populer Science en famille dengan judul "La photographie a travers les corps opaque". Dalam artikel tersebut, ia mengkritisi pemahaman umum tentang fotografi yang biasanya dipahami sebagai hasil induksi cahaya alami (natural light). Bagi Santini, fotografi adalah hasil induksi radiasi fisika yang melibatkan pelbagai unsur lain seperti elektrik, radiasi katoda, dan lain-lain. Singkatnya, melibatkan apa yang saat ini disebut sebagai radiasi sinar-X (X-ray) radiation). Ia mengakhiri artikelnya dengan menyimpulkan efek induksiimaji fotografi dengan istilah sebagaimana judul artikelnya: "fotografi dimaknai sebagai sebuah bingkai buram" (photography by means of an opaque body). Santini tidak sendirian. Pada 1905, Camille Flammarion, yang adalah juga seorang ahli astronomi Prancis, juga menulis serangkaian artikel yang dibukukan dengan judul La caprices de la foundre. Dalam bukunya ini, Flammarion menunjukkan "gambar-gambar lain yang dibuat oleh cahaya" yang bisa disandingkan dengan fotografi. Misalnya, sebuah sambaran cahaya petir yang 'mencetak' huruf-huruf metalik di dompet kulit, atau sambaran cahaya petir yang meninggalkan jejak mirip garis "yang nyaris sama seperti pohon pinus" di kulit orang yang hampir tersambar petir. ${ }^{13}$

Apa yang diusahakan Santini dan Flammarion adalah mencoba merumuskan fenomena di atas sebagai proses fotografi yang asli, dalam kerangka menjelaskan ‘temperamen’ pencahayaan. Gambar-gambar yang 
dihasilkan merupakan sebuah 'reproduksi', sebuah kulit atau "kertas sensitif" dari sebuah proses reproduksi alami. Di sini terletak definisi minimum fotografi: "sebuah tubuh yang memasukkan imajinya ke dalam tubuh yang lain" (a body inscibes its image onto another body). ${ }^{14}$ Proses reproduksi atau penciptaan salinan ini bisa terjadi melalui kontak fisik yang langsung maupun dari jauh, namun medium utamanya tetap adalah pencahayaan (lighting), dan terjadi dengan cara yang natural, atau dengan kata lain, spontan (by itself), tanpa bantuan manusia.

Sebelum kini secara umum digunakan istilah 'fotografi', Johann Heinrich Schulze, yang kerap disebut sebagai inventor fotografi, dalam rangkaian eksperimentasinya pada 1772, menggunakan istilah Scotophorus ("pembawa kegelapan") untuk menekankan efek lain pencahayaan dalam proses reproduksi fotografi, yaitu "tergelapkan oleh matahari" (darkened by the sun). ${ }^{15}$ Neologisme Schulze ini merumuskan ambivalensi sebuah proses penciptaan imaji, namun juga kemungkinan penghancuran imaji. Penyebab imaji adalah cahaya, namun serentak penyebab penghilangan imaji pun karena terlalu banyak cahaya. Dengan kata lain, cahaya digambarkan sebagai sesuatu yang memiliki kualitas penglahir-imaji dalam fotografi, namun serentak cahaya juga dilihat sebagai faktor yang perlu diwaspadai, disiasati, bahkan dilawan, sebab material yang dibutuhkan untuk fotografi perlu dilindungi dari kehadirannya. Singkatnya, cahaya adalah faktor penentu dan juga pengganggu proses ini.

Dengan demikian, fotografi bukanlah kegiatan yang sepenuhnya calculable, sebab selalu ada kemungkinan tidak terprediksi. Fotografi adalah suatu kolaborasi kesadaran dan ketidaksadaran, yang natural dan yang kultural, faktor-faktor yang sebagian sudah ada jauh sebelum kata 'gambar' dan 'foto' terumuskan, atau bahkan tanpa kaitan atau sebab asali dari yang dikenal kini. ${ }^{16}$ Dilihat dari sudut pandang ini, fotografi adalah sebuah peristiwa (event), dan imaji yang dihadirkannya bisa disandingkan dengan seni-seni lain: sebuah archeiropoetia, sesuatu yang tercipta not by man's hand, atau biasa disebut sebagai "imaji-imaji yang-mencipta-sendiri" (self-generated images). Istilah-istilah ini bukan untuk menandakan apa atau siapa yang harus dicoret atau tidak perlu diperhitungkan sebagai pencipta imaji, tetapi lebih menunjuk pada suatu ketidakhadiran (absence): bukan sekadar absensi dari intervensi (tangan) manusia, tetapi juga dari intervensi apapun yang dihadirkan imaji itu sendiri. 
Di sini, orang berurusan dengan apa yang disebut Georges DidiHuberman sebagai "jejak-jejak ilahi" dalam fotografi. ${ }^{17}$ Didi-Huberman mengingatkan bahwa kritik konstruktif atas fotografi senantiasa berisiko "losing sight of photografic power itself, as well as the (problematic) point where the image touches the real". ${ }^{18}$ Baginya, imaji fotografi tidak sekadar berhubungan (contacts) dengan apa yang real, tetapi lebih daripada itu, menyentuh (touches) apa yang real. Artinya, kekuatan fotografi sama seperti kekuatan seni-seni yang lain, tidak mengijinkan seseorang menggenggam sepenuhnya realitas, namun lebih seperti goyangan yang tidak pernah selesai antara "prosedur formal-teknis" berkesenian dan apa yang 'real' yang bersikeras untuk selalu dianalisis. Bisa dibandingkan dengan formulasi dari Claude Bernard, seorang psikolog Perancis, yang berbicara soal fraire apparaitre, sebuah "proses menampilkan" (a bringing into appearance) atau 'menampakkan' (making appear). Seorang fotografer yang masuk ke dalam kondisi pengalaman macam ini "membuat sebuah penampakan". ${ }^{19}$ Ia membuat sesuatu muncul ke permukaan, yang tetap akan tidak terlihat tanpa intervensinya, sesuatu yang sudah ada dalam imaji, yang bagaimanapun, tidak "bisa-dibuat".

Bahkan dalam sebuah kegiatan berkesenian yang kerap kali dikelaskan secara berbeda dari seni-seni lain, imaji-imaji dalam fotografi didasari atas interaksi tidak berkesudahan antara kontrol dan disorientasi, formasi dan kebetulan, intervensi dan sifat tidak-terprediksi seluruhnya, sumbangan atas nama fotografer dan juga atas nama mesin fotografi. Bila imaji dirumuskan, baik dalam fotografi ataupun dalam medium yang lain, sebagai kodifikasi jarak konvensional antara ekspresi dan isi, akan ditemukan banyak 'pengkhianatan' yang juga bisa ditemukan dalam kata-kata, khususnya dalam puisi atau karya-karya sastra. Fotografi memfigurasikan itu semua dengan cara yang dengannya, menurut Roland Barthes, sebuah foto secara unik dan asing merepresentasikan sebuah pesan yang tidak terkode (uncoded) ${ }^{20}$ Di titik ini, pertanyaan yang pantas diajukan tidak lagi apa yang membuat imaji terlihat atau bagaimana yang-terlihat dari imaji itu termaterialisasikan, melainkan apa yang-tidak-terlihat atau yang-tidakterkatakan dari sebuah imaji. 


\section{Yang-Tidak-Terlihat dan Yang-Tidak-Terkatakan dalam Imaji}

Imaji (image, Latin: imago, Yunani: eikon, Ibrani” tselem) adalah sesuatu yang berlimpah dalam keseharian, namun bukanlah sebuah kata yang mudah untuk didefinisikan, atau sebuah undecidability. Sering digunakan kiasan-kiasan keseharian untuk menggambarkan apa itu imaji. Misalnya, ungkapan yang sulit diterjemahkan: "you can hang a picture, but you can't hang an image." Namun, ketika harus merumuskannya, orang akan tiba pada pemikiran yang rekursif dan repetitif. Konsep pada dirinya sendiri adalah sebuah imaji, dan imaji pada dirinya sendiri ada dalam konsep. ${ }^{21}$ Mempertanyakan "Apa itu imaji?" berarti mengharapkan sebuah 'ide' tentang imaji, sedangkan 'ide' itu sendiri sudah senantiasa terikat dengan imaji-'ide' berasal dari Bahasa Yunani eidos, 'melihat'. Oleh karenanya, ketimbang berkutat pada persoalan definisi, lebih produktif bila dibicarakan sebuah "retorika imaji" dalam dua arti. Pertama, mengenai apa yang harus dikatakan tentang imaji, dan kedua, apa yang dikatakan oleh imaji.

Salah satu cara untuk memikirkan imaji dengan berbagai kata-kata kaitannya adalah dengan melihatnya sebagai rangkaian keluarga-jauh yang telah bermigrasi bersamaan dengan ruang dan waktu dan telah terjadi mutasi yang mendalam dalam prosesnya. Di sini, orang bahkan bisa membuat semacam genealogi imaji, dan juga tempat-tempat atau lokasi imaji telah bermutasi dan menjadi berbeda satu sama lain dengan dasar batas-batas wacana institusional yang berbeda. W. J. T. Mitchell menggambarkan "pohon keluarga" seperti berikut. ${ }^{22}$

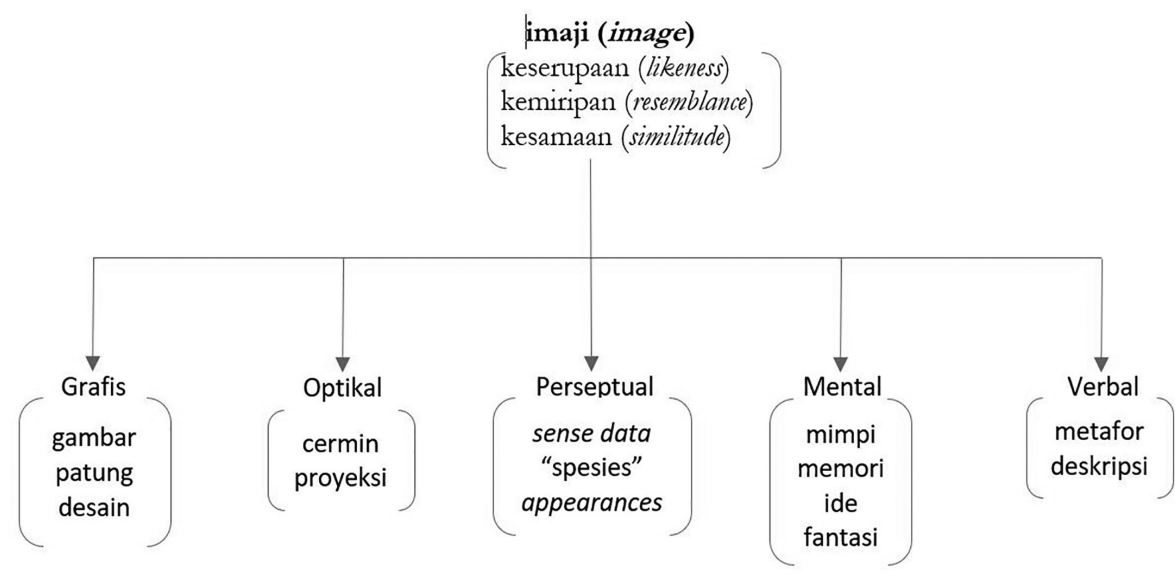


Setiap cabang dari pohon keluarga ini menandakan sebuah tipe imaji yang sentral dalam wacana disiplin intelektual. Imaji mental milik psikologi dan epistemologi. Imaji optikal merupakan wacana fisika. Imaji grafis ada dalam wilayah arsitektur dan sejarah seni. Imaji verbal ada dalam kritik sastra. Imaji perseptual menempati semacam batas-batas tempat fisikawan, neurolog, psikolog, sejarawan seni, menemukan diri mereka sedang berkolaborasi dengan para filsuf dan kritikus sastra. ${ }^{23}$

Pada wilayah batas ini ditemukan beberapa "mahluk aneh" yang menghantui batas antara fisika dan psikologi yang berkaitan dengan imaji: 'spesies' atau "bentuk sensible" yang menurut Aristoteles berasal dari objek-objek dan mencetak diri mereka sendiri ke dalam sejenis wadah mirip lilin dari indra-indra seseorang seperti sebuah cincin meterai; sense data atau percept yang kurang lebih memainkan peran yang mirip dalam psikologi modern; dan appearances yang menyelinap di antara diri seseorang dan realitas, yang umumnya diacu juga sebagai 'imaji'. ${ }^{24}$

Sejauh ini hanya bisa diduga bahwa berbagai terminologi imaji adalah hasil dari sejenis drift metaforis, sebuah usaha pencarian analogi konkret yang terliterasikan di bawah bayang-bayang trial and error dan terhubung pada hipotesis saintifik yang teruji terhadap fakta-fakta yang terlihat. Atau dengan bahasa lain, seperti dikatakan Ernst Gombrich, proses pembuatan "hipotesis gambar" (pictoral bypothesis) selalu mendahului "proses pencocokan" hipotesis-hipotesis tersebut terhadap dunia yang terlihat. ${ }^{25}$ Proses pencocokan ini adalah sesuatu yang alami dan manusiawi karena "tidak ada penglihatan (vision) tanpa tujuan, dan bahwa mata yang polos adalah buta (innocent eye is blind)," kata Gombrich. ${ }^{26}$ Namun, bila vision itu sendiri adalah hasil dari pengalaman dan akulturasi, apa yang sedang dicocokkan di hadapan representasi pictoral bukanlah sejenis realitas yang telanjang, tetapi sebuah dunia yang sudah senantiasa dibungkus (clothed) dalam sistem representasi manusia. ${ }^{27}$

Hal tersebut berarti bahwa selebat apapun pohon keluarga imaji di atas itu dengan ranting-rantingnya yang berjuntai, ada satu hal yang tidak bisa diabaikan, yakni kesadaran (consciousness), yang mengambil bagian terpenting di sini. Kesadaran umumnya dipahami sebagai keseluruhan aktivitas produksi, reproduksi, dan representasi bergambar yang diatur oleh mekanisme mirip lensa, dan permukaan-permukaan reseptif, dan aktivitas 
ini meninggalkan jejak-jejak pada permukaan-permukaan itu. ${ }^{28}$ Kesadaran (pikiran) menjadi elemen penting di sini karena jika diandaikan sudah tidak ada lagi kesadaran (pikiran), bisa jadi tidak ada lagi imaji, baik mental maupun material. Dunia mungkin tidak tergantung pada kesadaran, tetapi imaji dalam dunia tergantung padanya, apalagi terkait kesadaran tentang dunia. Ini bukan hanya karena imaji 'membutuhkan' tangan manusia untuk dilahirkan dalam gambar, pantulan, atau simulakrum lain, tetapi karena sebuah imaji tidak bisa dilihat begitu saja tanpa trik paradoksal kesadaran, sebuah kemampuan untuk melihat sesuatu sebagai "di sana" dan serentak "tidak di sana". ${ }^{29}$

Bila meminjam strategi dari tradisi Platonik yang membedakan antara eidos dan eidolon, sementara eidos merujuk pada "realitas supersensible" (supersensible reality) dari "bentuk, tipe, atau spesies" dan eidolon berarti impresi yang teraba (sensible impression) yang menyediakan kepada kesadaran semata-mata suatu 'keserupaan' (likeness, eikon) atau 'kemiripan' (semblance, phantasma) dari eidos. Apa yang harus dikatakan tentang imaji adalah bahwa istilah ini harus dilihat sebagai gagasan yang bukan pictoral, bukan sebagai gambar material, melainkan sebagai 'keserupaan' abstrak, umum, dan bahkan spiritual. ${ }^{30}$

Selain jalur tradisi filsafat, ritme historis tradisi agama Kristen pun memberikan penekanan pada aspek di atas. Kitab Kejadian memperdengarkan bagaimana Tuhan menciptakan manusia sesuai image and likeness-Nya. Manusia adalah imaji dan keserupaan dari penciptaNya, yakni imago dei. Akan tetapi, tidak ada tradisi agama yang menafsirkan dua istilah ini-image dan likeness-sebagai sesuatu yang material. Bahkan, istilah 'keserupaan' (likeness, Latin: similitude, Yunani: homoious, Ibrani: demuth) dimengerti bukan sebagai info tambahan untuk imaji, melainkan untuk mencegah kebingungan yang mungkin timbul, bahwa imaji harus dimengerti bukan sebagai sebuah 'gambar', tetapi sebagai 'keserupaan', atau sebuah perkara kemiripan spiritual. ${ }^{31}$ Sejarah ikonoklas (iconoclasm) adalah bukti ketika ketidakmampuan mata dan akal budi manusia membedakan yang material dan spiritual bisa berakibat fatal: penghancuran dan pertumpahan darah untuk sebuah kenyataan yang tidak bisa dipungkiri dan bahwa imaji tidak bisa dihancurkan.

Gambar adalah sebuah objek material, sesuatu yang bisa dibakar, dihancurkan, atau dirobek. Sebuah imaji adalah apa yang muncul dalam/ 
dari sebuah gambar, dan apa yang bertahan ketika sebuah gambar/ lukisan/patung dihancurkan-imaji bertahan dalam ingatan, narasi, salinan, dan jejak di media lain. Ini artinya gambar adalah imaji sebagaimana ia muncul dalam sebuah medium atau yang lainnya, tetapi ia juga adalah apa yang melampaui mediumnya, apa yang bisa ditransfer dari satu medium ke medium yang lain. Imaji adalah sebuah entitas yang sangat abstrak dan agak minimum yang dapat dibangkitkan dengan sebuah kata. Cukup menamakan sebuah imaji untuk membawanya ke dalam pikiran, yaitu untuk membawanya ke dalam kesadaran dan sebuah tubuh yang mengamati dan mengingat. ${ }^{32}$

Maimonides dapat membantu menggarisbawahi apa yang dirujuk oleh istilah 'imaji' ini. Bagi Maimonides, imaji secara literal adalah realitas esensial sesuatu, dan hanya melalui sejenis pembusukan (corruption) yang menjadikan sebuah imaji diasosiasikan dengan sesuatu yang bertubuh (corporal) akhirnya dilihat sebagai idol.

"Alasan mengapa idol disebut imaji terletak pada kenyataan bahwa apa yang terlihat dari imaji-imaji itu dianggap hidup (subsist) dalam imajiimaji tersebut, dan bukan sekadar hidup (subsist) dalam bentuk (form) atau konfigurasi. Imaji yang sejati, yang literal adalah apa yang mental atau yang spriritual itu; imaji yang keliru (improper), yang derifatif, figuratif adalah bentuk-bentuk material yang diterima oleh indra kita, khususnya mata." 33

Tidaklah mengherankan bila Maimonides menyebut imaji sebagai istilah yang "hidup dalam dua alam" (amfibi, amphibolous) yang bisa saja mengacu pada "bentuk spesifik" (yaitu identitas atau "spesies" dari sesuatu) atau "bentuk (form) artifisial" (bentuk [shape] korporal mereka)..$^{34}$ Akan tetapi, Maimonides dengan jelas membedakan kedua istilah itu dan yakin tentang mana yang orisinal dan autentik, mana yang berasal dari aplikasi yang keliru.

Mungkin agak sulit untuk membedakan antara makna 'spiritual' dan aplikasi 'material' dari imaji, dan ini karena umumnya pengertian orang tentang istilah imaji (dan juga untuk hampir semua kata-kata lain) sudah senantiasa terorientasi di sekitar epistemologi empiris. ${ }^{35}$ Orang terbiasa berpikir empiris-praktis, cenderung berpikir pada apa yang paling konkret, aplikasi material dari sebuah kata tertentu ketimbang apa yang orisinal, apa yang primitif. Sampai di sini bisa dilihat pemahaman imaji sebagai 
sebuah 'kemiripan' spiritual, tersentuh oleh pemahaman (kesadaran), sebuah sentuhan pada kenyataan ultimnya, ketika imaji dimengerti sebagai kedalaman (inward) dan tidak-terlihat. Artinya, imaji selalu ada dalam gambar, lukisan, patung, atau hasil karya seni apapun yang menanti untuk dirumuskan dengan cara baru, menanti bahasa untuk menangkapnya dengan gambaran yang menarik. Dalam arti ini, imaji sudah selalu pergi sebelum kata, dan mendahului masa depan. Masa depan imaji adalah sudah selalu sekarang, dalam bentuk imaji dalam medium yang senantiasa terbarukan, yakni imaji dari yang akan datang, ${ }^{36}$ sebuah imaji dari apa yang belum datang, tetapi sudah ada dalam horizon. Oleh karenanya, salah satu karakter imaji yang dipahami demikian adalah bahwa ia 'bergerak'.

Pemahaman ini merumuskan tujuan utama pengerjaan seni yang menciptakan imaji-imaji, yang bisa jadi menghasilkan hasil karya yang wanted nothing at all, menghasilkan sejenis utopia estetis yang melampaui desire, ruang bermain dan retribusi yang emansipatoris. Seni yang demikian akan "menghasilkan sesuatu yang persis terletak dalam kenyataan bahwa mereka tidak melakukan apa pun dan menginginkan apapun". ${ }^{37}$ Dengan jalan yang berbeda, Maurice Blanchot memberikan penjelasan soal ini dalam esainya, The Two Versions of the Imaginary. Menurutnya, ada kesamaan esensial antara imaji dan mayat (corpse), dalam arti bahwa "imaji membutuhkan netralitas dan memudarnya dunia; kalaupun ada yang diinginkan imaji, ia menginginkan segala sesuatu untuk kembali pada kedalaman yang tak berpihak (the indifferent deep) ketika tidak ada sesuatu yang bisa diaffirmasi; imaji cenderung pada keintiman dari apa yang masih hidup (subsist) dalam kehampaan (void)." ${ }^{38}$ Mayat dan imaji tidak dapat direduksi menjadi apapun. Mereka adalah kesatuan anonim, masing-masing memiliki keserupaan (likeness) tanpa objek, tanpa referensidiri (self-reference). Imaji (dan juga mayat) adalah relasionalitas nonrelasional yang sangat gelap dari bayangan yang menolak struktur dialektika Hegel. Bagi Blanchot, imaji adalah keterbukaan untuk menerima ketiadaan yang terberikan, yang adalah juga, dengan caranya sendiri, 'terberikan'. ${ }^{39}$

Pada saat imaji melakukan dan menginginkan sesuatu, hadirlah sebentuk ikonoklas dalam bentuknya yang paling keji, yakni fetisisme dan idolatri (idolatry of the spectacle). Salah satu karakter yang dominan dari imaji adalah, seperti disinggung di atas, kebergerakan (moving, circulating, migrating): imaji sudah senantiasa "tiba dan muncul" di suatu tempat; imaji 
senantiasa mencari tempat tinggal sementara, tubuh yang fana, tempat 'roh' imaji terinkarnasi, sebuah "transmigrasi jiwa-jiwa". ${ }^{40}$ Akan tetapi, tendensi okularsentrisme membawa mental penjajah, ketika ia mengusir dan menghancurkan imaji di halaman rumah temporal mereka sendiri, mencegah kemungkinan imaji untuk bermigrasi. Kitab Bilangan 33:52 dalam Kitab Suci kristiani, menampakkan proses serentak penghancuran, pemindahan situs-situs suci, dan juga para penghuninya dalam satu gerakan. Situs-situs dan orang-orang pribumi adalah satu kesatuan, imajiimaji yang saling berhubungan, dan identitas yang tidak terpisahkan. Di sini bukan sekadar pemusnahan, tetapi sebuah genosida imaji dengan maksud menaklukkan dan mengontrol imaji. Karakter imperialistis okularsentrisme menjadikan imaji apa yang disebut oleh Mitchell sebagai "objek buruk" (bad object) atau "objek untuk yang lain", ${ }^{41}$ yakni barang rampasan yang diyakini kesucian dan aura magisnya oleh penduduk setempat, namun dipandang sekadar objek tidak berharga, menjijikkan, bahkan dirasa penting untuk dimiliki, digenggam, dikoleksi, dan dipertontonkan karena ini adalah bukti kemenangan dan validitas kekuasaan. Di titik ini, imaji menjadi sebuah "objek-imaji"; ini adalah saat ketika imaji menjadi komoditas fetisisme.

Dalam bentuknya yang lebih awal, "objek-imaji" ini bisa juga menjadi idol. Ini terjadi saat agresivitas menjajahnya okularsentrisme berhenti pada materialitas imaji dan merayakannya sebagai sesuatu yang "melampaui materialitas"nya sendiri. Ini seperti kisah Israel setelah keluar dari tanah perbudakan dan menuju Tanah Terjanji, mereka meminta Harun untuk "membuat bagi mereka tuhan yang akan berjalan di depan mereka" (Keluaran 32), yakni sebuah patung lembu emas yang akan mengambil tempat pemimpin yang mereka pikir telah hilang, yakni Musa. Atau, seperti seorang kaisar yang menganggap dirinya dewa, yang imajinya disebarluaskan melalui patung dan pada koin, ia sedang menjadikan dirinya pusat simbol dan inkarnasi dewa. Idol adalah imaji imperial yang hendak berkuasa, menghadirkan ancaman dan tuntutan yang serius. Sebuah idol menuntut pengorbanan, dan harga yang dibayar untuk pelanggarannya adalah nyawa.

Di hadapan fetisisme dan idolatri semacam ini, pandangan tentang imaji adalah seperti "tatapan Medusa", menyedot kering kebergerakan imaji dan menjadikannya bad-objek, yang menanti untuk mati. Namun, imaji yang sekarat, karena sebenarnya tidak pernah bisa sepenuhnya 
mati, akan menatap balik dengan tatapan yang sama, dan siapapun yang mencoba melihatnya akan menjadi "Medusa-Medusa" yang lain. Mungkin ini adalah salah satu tantangan sekaligus persoalan serius yang dihadapi sinema kini. Film, sebagai seni imaji-beranjak, mesti berusaha agar imajiimaji yang terpantul pada media yang tersedia saat ini senantiasa membuka kemungkinan kebergerakan. Ini adalah usaha nyata untuk menjaga dan merawat imaji-imaji, dengan menggunakan kecanggihan teknologi saat ini, agar siapapun yang menatapnya tidak menjadi "Medusa-Medusa" modern, ketika imaji menjadi komoditas fetisisme dan idolatri. Opini Scorsese yang dirujuk di awal tulisan ini memberikan kata-kata kunci dengan bahasa yang lebih sederhana, agar terhindar dari bahaya fetisisme dan idolatri: ketidakterdugaan (unexpectedness) dan resiko (risk), tanpa terputus koneksinya dengan pengalaman hidup yang nyata.

\section{Okularsentrisme: The Lust of the Eye}

Salah satu faktor pendukung atau mungkin penyebab tergerusnya imaji dan lahirnya Medusa-Medusa modern adalah tendensi okularsentrime dalam budaya visual. Secara singkat, okularsentrisme memberikan keutamaan (privilege) pada indra penglihatan ketimbang indra-indra yang lain. ${ }^{42}$ Pengertian ini tidak berarti bahwa orang lebih sering menggunakan mata ketimbang indra-indra lain, ${ }^{43}$ namun bahwa tendensi ini bergerak lebih jauh dan lebih dalam sampai pada pola pikir yang memberikan nilai lebih untuk pengetahuan yang diperoleh secara visual ketimbang lewat proses mendengarkan, menyentuh, atau proses kinetik lain. Pada titik tertentu, pengetahuan bersifat analog dengan penglihatan. ${ }^{44}$ Pengutamaan apa yang visual tersebut berdampak jauh pada cara orang memahami pengetahuan dan mendapatkan pengetahuan. Marshall McLuhan mengamati bahwa "benturan budaya" terbesar bukanlah Timur-Barat, melainkan benturan mata dan telinga: "tidak mungkin ada kontradiksi dan benturan dalam budaya manusia ketimbang kontradiksi dan benturan yang diwakili oleh mata dan telinga." ${ }^{45}$ Walter Ong memberikan sebuah explorasi menarik bahwa efek benturan budaya ini sampai pada titik orang tidak lagi bisa merasakan interioritas atau senantiasa berusaha menyentuh interioritas sebagai exterioritas: 
"Penglihatan hanya menampilkan (reveals) permukaan. Ia tidak pernah bisa sampai ke interior sebagai interior tetapi harus selalu memperlakukannya sebagai eksterior. Jika pemahaman dipahami dengan analogi penglihatan saja ... pemahaman (understanding) ipso facto dikutuk untuk menangani permukaan yang memiliki sesuatu 'di balik'-nya yang tidak akan pernah bisa dicapai. " 466

Observasi atas gelagat okularsentrisme dalam budaya kontemporer tidaklah berlebihan, terutama di wilayah filosofis. Orang terlalu sering mengandalkan diri pada perbendaharaan kata dan cara berpikir yang senantiasa memiliki acuan pada metafor okular. Dalam kehidupan sehari-hari, digunakan idiom-idiom okular seperti I see ("saya mengerti"), overlooking (abai), see eye to eye (persetujuan), sampai ungkapan rasa pun harus mengacu pada yang visual seperti an apple to my eye (rasa sayang dan suka), dan masih banyak lagi contoh lain yang bisa ditemukan dalam keseharian. Dalam wacana filosofis, acuan okular bisa didapati dalam katakata kunci filsafat seperti speculation, insight, reflection, point of view, horizon of understanding, the light of reason, theater, theory, contemplation, perspective. Beberapa contoh metodologi filosofis yang menggunakan acuan okular misalnya totality, analysis, objectivity, reflective, detachment, representation, dan masih banyak lagi. ${ }^{47}$ Kaja Silverman memberikan gambaran tentang obsesi manusia pada visualitas:

"Visualitas adalah bentuk keterlibatan etis kita yang paling signifikan dan utama dengan dunia, penyempurnaan terus menerus dari teknologi penghasil-gambar seperti fotografi dan sinema, dan penyebarannya dalam berbagai wilayah kehidupan, mulai dari kegiatan waktu luang hingga perang dan teknologi perlindungan keamanan (surveillance), tampaknya membenarkan klaim bahwa masyarakat modern terobsesi dengan dan dibentuk oleh tontonan dan gambar." 48

Sejak awal filsafat, pentingnya penglihatan terbukti melalui tulisantulisan Plato. Dalam Timaeus, misalnya, Plato membedakan antara penciptaan berdasarkan indra penglihatan (yang ia kelompokkan dengan penciptaan jiwa dan intelegensi manusia) dan dari indra yang lain (yang ditempatkan dalam being material manusia). Ia mengklaim bahwa "mata adalah organ yang terluhur" (the noblest sense) pada manusia, ${ }^{49}$ bahkan bisa dikatakan bahwa mata adalah prototipe organik filsafat, ekspansi "organ eksosomatik" (exosomatic) yang memperluas jangkauan tubuh, mengkompensasikan apa yang kurang dari kebertubuhan seseorang. ${ }^{50}$ Mata juga adalah "organ efisiensi" manusia. Seseorang melihat melalui 
mata, bukan dengan mata. Enigmanya adalah bahwa mata tidak hanya bisa melihat, tetapi juga bisa melihat dirinya yang sedang melihat. ${ }^{51}$ Sejak zaman Yunani, tulisan-tulisan filosofis sudah terikat pada metafor okular sampai pada titik bahwa pengetahuan pun menjadi analog dengan vision yang jelas dan cahaya dianggap sebagai metafor kebenaran. Mitos gua yang terkenal itu, juga sangat bergantung pada mata. Apa yang sejati tidak terlihat di dalam gua, sebab orang hanya mampu merasakan bayangannya saja, dengan cara melihat. Dan hanya bila sudah keluar dari gua, orang terbebas dan bisa melihat dengan lebih jelas, tanpa bayang-bayang. Namun, kisah ini juga menyelipkan kecurigaan terhadap mata: ketika api tergantikan oleh matahari sebagai sumber cahaya yang terlalu terang untuk bisa langsung ditatap, mengimplikasikan kecurigaan Plato terhadap ilusi dari indra persepsi. Plato mengatakan pada Timaeus bahwa penglihatan adalah anugerah terbesar manusia, namun juga mengingatkan adanya ilusi di mata-cara pandang seseorang-yang tidak sempurna. ${ }^{52}$

Karakter okularsentrisme ini semakin digarisbawahi dalam filsafat modern, dan peringatan Plato itu terbukti pada Abad Pencerahan melalui filsafat Descartes yang kerap disebut sebagai Bapak Pendiri Paradigma Visualis Modern. Descartes tidak sekadar bertanggung jawab menyediakan justifikasi filosofis untuk kebiasaan epistemologi modern dari 'melihat' ide dalam pikiran, tetapi juga pendiri tradisi identitas reflektif-spekulatif, ketika subjek teryakini hanya pada pantulan-pantulan imajinya saja. ${ }^{53}$ Bagi Descartes, pikiranlah yang mengindra, bukan tubuh. Jarak, lokasi, ukuran, dan bentuk hanya ada di dalam pikiran. Persepsi yang "jelas dan tegas" (clear and distinct) adalah sesuatu yang self-evident, tidak teragukan. Untuk menegaskan hal ini, ia merombak analogi kebersentuhan: ia tidak punya tubuh, dan menyimpulkan eksperimennya dengan tajam: "aku yang ini (this me)-inilah, jiwa yang mana aku adalah aku-yang secara sempurna terpisahkan dari tubuh; dan bahkan lebih mudah mengetahui ketimbang tubuh." 54

Dalam pemikiran Descartes, manusia diasumsikan sebagai karakter subjektif distingtif, yang memproklamasikan kemenangannya, bahkan di dalam pesan-pesan ketika ia sedang mendemostrasikan keberadaan Tuhan. ${ }^{55}$ Akan tetapi, ada ambiguitas dan paradoks dalam pembuktian ini: apa yang sungguh-sungguh dirayakan adalah kekuatan akal budi manusia, memprioritaskan 'manusia' dibanding Tuhan yang sedang dibuktikannya, 
dan hasilnya adalah subjek yang independen (self-independent), berkehendak bulat (self-determination), dan afirmatif (self-affirmation). ${ }^{56}$ Apa yang dilakukan Descartes adalah mengalihkan pandangan manusia dari langit dan surga, dan memproyeksikan pada dunia kehidupan manusia. Konsekuensinya adalah sebuah pemahaman akal budi yang egologis dan konsep diri yang antroposentris: sebuah akal budi yang instrumental, pragmatis, dan praktis. ${ }^{57}$ Pemahaman semacam ini terbukti membawa berbagai kemajuan teknologi terapan yang tidak terpikirkan sebelumnya, namun di sisi lain, perlahan-lahan membawa juga konsep diri tersembunyi yang lain, yang merusak (self-destructive). Manusia lambat laun mulai mengaburkan, bahkan menghilangkan pandangan bahwa ada perbedaan jelas antara akal budi dan kebenaran, bahwa kebenaran itu sangat berbeda dari kekuasaan. Saat akal budi menjadi sekadar instrumental dan sebuah fungsi kekuasaan, ialah yang melegitimasi konstruksi negara totalitarian dan merancang Holocaust. ${ }^{58}$ Salah satu warisan humanitas modern adalah teror.

Persoalan dalam struktur pengetahuan Descartes antara lain adalah kecenderungan mempolarisasi subjek dan objek serta memposisikan keduanya dan menguatkan simpul-simpul kesakitan yang ditarik berlawanan: tarikan ego-subjek (yang 'melihat') dan di sisi lain, objek (yang 'terlihat') yang berusaha lari menjauh. Salah satu kebutuhan ego-subjek semacam ini adalah sekuritas, yakni sebuah kebutuhan metafisik dalam "petualangan untuk kepastian". Sang Ego selalu dan perlu terikat pada apa yang diyakini sebagai kepastian. ${ }^{59}$ Ego jenis ini adalah ego yang melihat dengan pandangan agresif: ada tendensi kuat dalam tatapan terpaku manusia modern untuk menangkap, mereifikasi, dan mentotalisasi. Dengan bahasa lain: sebuah tendensi mendominasi, mengamankan, mengontrol, dan menyeragamkan. Tendensi 'predatorik' pada subjek yang seperti ini, dan apa yang dibawa ke depan, menjadi jelas bagi mata dan menjadikan setiap objek visible, direpresentasikan, akan menderita. Itu seperti kamera yang menangkap segala sesuatu di depannya sebagai (calon) mangsanya.

Persoalanlain hasratrepresentasi subjek Cartesianadalah adanya karakter memaksakan pada apa pun juga, yakni sebuah metafisika objektivitas. Segala sesuatu yang hadir harus menghadirkan dirinya sendiri untuk representasi, dan hanya representasi ini dianggap sebagai nyata. Ini adalah bentuk subjektivitas paling ekstrim, yang secara inheren mengorganisasi segala sesuatu di seputar pengoposisian, konflik, pergumulan, dan kekerasan. 
Berbagai persoalan metodologis ini mendorong manusia-manusia kontemporer masuk ke dalam detasemen (detachment, keterpisahan subjek dengan objek, dengan dunia, dengan realitas, dengan yang lain), isolasi (pengasingan apapun yang dikelompokkan sebagai objek, dan subjek yang dingin menyendiri), dan eksterioritas (sebagaimana digambarkan Walter Ong di atas). Detasemen, isolasi, dan eksterioritas yang dibawa oleh visualisme modern ini juga serentak menghilangkan apa yang disebut Ponty sebagai tubuh yang merasakan pengalaman-pengalaman, ${ }^{60}$ dan membawa orang pada nihilisme dalam arti matinya emosi-emosi manusiawi. Apapun yang ditatapnya, sebagaimana Medusa menatap, termasuk di dalamnya imaji-imaji, menderita dan perlahan-lahan mati.

Pada awal kisah Penciptaan kristiani digambarkan bahwa manusia adalah imago dei, dan dunia adalah suatu imaji yang terlihat hanya melalui Tuhan. Dalam Abad Pencerahan dan Renaissance, orang merebut tempat dan cara Tuhan melihat itu dalam dunia tergambar, tetapi apa yang dihadirkan gambar tersebut adalah apa yang terlihat hanya bagi manusia. Pada zaman ketiga ini, saat ini, dunia yang dihidupi akhirnya direduksi pada ontologi gambar-gambar, hanya untuk manusia: ${ }^{61}$ Seeing is believing. Akan tetapi, mata bukanlah satu-satunya organ untuk mengetahui, dan bukan satu-satunya sumber kebenaran. Dari kisah Tomas, salah satu rasul Yesus, yang terlukis dengan sangat indah dalam The Incredulity of Saint Thomas-nya Caravaggio, orang menyadari justru matalah yang menjadi sumber keraguan dan karenanya harus dipuaskan melalui mata, namun ini dipertanyakan bila sumbernya saja meragukan. Apa yang dimiliki mata adalah sejenis birahi (lust), dan birahi niscaya selalu datang kembali (The Lust of the Eye). Adalah jemari Thomas yang menyentuh fisikalitas kebangkitan Tuhan, dan karenanya kebangkitan Kristus dibuat kembali menjadi lebih gamblang. ${ }^{62}$ Oleh karenanya, pesan Kristus kepada para murid-Nya adalah sejenis Sabda Bahagia yang lain: berbahagialah mereka yang tidak melihat-Nya, namun percaya, karena kebahagiaan karena percaya kepada-Nya juga bisa melalui jalan-jalan lain: mencicipi-Nya, menyentuh-Nya, mendengarkanNya.

Jacques Ellul, dari titik berangkat teologi, mengingatkan tendensi "lust of the eye" ini yang mengubah arah teologi dari logos ke idoloatry. Abad Pencerahan adalah masa ketika terjadi "pesta pora gambar" yang sangat serius sampai pada titik memusuhi dan hendak menggantikan logos. Permusuhan ini bahkan bisa didengar gaungnya sampai saat ini 
dan terekam dengan baik dalam ungkapan-ungkapan keseharian seperti We believe what we see, sementara What we hear is hearsay (kabar angin), dan "Lebih baik melihat satu kali daripada mendengar ribuan kali," dan lainlain. Bila pada kisah Penciptaan didengar bahwa pada mulanya segala sesuatu adalah Logos (Kata, Sabda), pada Abad Pencerahan manusia justru menutup kemungkinan peristiwa Anunsiasi (Penerimaan Kabar Gembira) datang kembali dan bergaung dalam kehidupan manusia. Seperti dijelaskan oleh Martin Jay, visualitas Pencerahan memotret realitas eksternal menjadi imaji-imaji tanpa durasi, sebuah kehadiran eksternal tanpa kesinambungan makna apapun antara masa lalu dan masa depan. ${ }^{63}$ Imaji visual menghasilkan objek di luar dirinya sendiri untuk memanipulasi manusia. Imaji tidak memberi kepadanya apapun selain penampakan dan kebiasaan eksternal, tidak juga makna ke dalamnya. Pembelaan Ellul pada logos ini dan pada pendengaran ketimbang visualitas, didasari pada kenyataan bahwa mendengarkan adalah sebuah dialog intersubjektif, yang memanggil untuk suatu respon penjelasan misteri-misteri dari teman bicara. Pandangan adalah seorang penonton (spectator), mendengarkan adalah seorang partisipan (partisipator). ${ }^{64}$ Imaji-imaji di sekitar logos cenderung menjadi benda mati bila berhadapan hanya dengan mata Pencerahan, namun bila melibatkan indra-indra lain, imaji menjadi teman bicara yang senantiasa menyingkapkan misteri.

Ada beberapa sumber penyebab okularsentrime menurut Ellul, seperti dituliskan Jay. Pertama, kodrat ganda cahaya (light). ${ }^{65}$ Dalam masyarakat purba ada distingsi dua model cahaya, lux dan lumen, sebuah distingsi yang pada akhirnya ditinggalkan karena implikasi problematiknya. Lux adalah yang terlihat; normalnya berarti fenomena cahaya yang dialami oleh mata manusia, yaitu warna dan bayangan. Sementara itu, lumen adalah yang tidak terlihat, yang menandakan aktivitas fisika dari gelombang cahaya atau seperti sel-sel darah (corpuscles) yang terlihat bila ada tubuh yang transparant. Oleh pemikir religius seperti Grostesque, lux dipahami sebagai iluminasi alami, yang profan, di dalam mata makhluk yang mortal, sedangkan lumen adalah cahaya utama yang dihasilkan oleh pancaran ilahi. Oleh pemikir sekular, seperti Descartes, lux diyakini sebagai gerakan atau tindakan yang terjadi di dalam wujud material yang bersinar maupun pengalaman iluminasi berwarna di dalam mata yang melihat; sementara lumen mengacu pada gerakan-gerakan corpuscular dalam media yang transparan. Bagi Descartes, lumen adalah subjek yang tepat untuk hukum 
geometrika katoprik (berkaitan dengan pantulan-pantulan, refleksi) dan dioptrik (berkaitan dengan pembiasan-pembiasan, refraksi), yang bisa dipelajari secara deduktif karena keduanya berhubungan dengan geometri alam pikiran. Dari dua sudut pandang di atas terlihat bahwa masih ada kebingungan untuk memahami perbedaan antara lux dan lumen secara praktis, dan karenanya digantikan oleh satu kata untuk keduanya, luce, yang artinya cahaya per se, yang umumnya membawa relasi hierarkis antara lux dan lumen. ${ }^{66}$

Kedua, diamati oleh Jay, bahwa apa yang biasanya disebut sebagai budaya 'kepenontonan' (specularity) sebagai model pengetahuan adalah semacam aktivitas reflektif dalam sebuah ruang kaca yang menghasilkan seorang subjek yang mengamati. ${ }^{67}$ Dari sini terlahir aktivitas-aktivitas seperti spekulasi, kontemplasi, dan bahkan teater yang merupakan terjemahan Latin untuk kata Yunani, theoria, yang berakar pada kata specio, yang berarti 'melihat' atau 'memandang'. Dalam filsafat, salah satu contoh utama 'spekularitas' dapat ditemukan pada filsuf identitas-idealis seperti Hegel. Menurut Hegel, seperti dikatakan Jay, kesatuan dialektis yang ultim Subjek dan Objek berakar dalam speculum Roh Absolut. ${ }^{68}$ Dalam ruang kepenontonan, vision tidak dipahami dalam arti sebuah mata yang melihat objek eksterior pada dirinya sendiri, namun lebih seperti mata yang melihat dirinya sendiri dalam refleksi tidak-berkesudahan (infinite reflection). Karenanya, spekulasi sering diidentikkan, meski tidak selalu sama, dengan pikiran dialektik, karena keduanya mengakui perbedaan antara subjek dan imaji-imaji, dan mensublasikannya (proses penegasian Hegelian) ke dalam kesatuan besar, identitas sintetik dari identitas dan nonidentitas. Implikasi problematiknya adalah di satu level, hal ini mengakibatkan bahasabahasa narsistik dan serentak solipsistik, sebuah dosa kesombongan yang merupakan versi lain perintah untuk berhati-hati dari "kenali diri sendiri" (to know oneself). Pada level yang lain, refleksi absolut mengandaikan asumsi berbahaya adanya kesatuan metafisik dan homogenitas universal. ${ }^{69}$

Ketiga, tambahan dari Juhani Pallasmaa, adalah penemuan apa yang disebut sebagai "representasi perspektival", yakni tendensi yang menganggap mampu menghadirkan kembali perspektif. ${ }^{70}$ James Gibson memberikan pembedaan etnografi atas persepsi kultural menjadi dua, yakni "dunia visual" dan "bidang visual". Yang pertama adalah dunia 
tempat semua indra berinteraksi dan manusia melihat kedalaman sehingga mampu membentuk dan mengetahui bahwa sebuah piring adalah bulat, sedang yang kedua tersebut adalah tempat mata terlepas dan menerima piring sebagai sesuatu yang elips (ellipse), yakni sebuah "bentuk proyeksi". 71 Dalam budaya tanpa perspektif hanya ada "dunia visual". Perspektif "membuat mata menjadi titik pusat dari dunia perseptual sebagaimana juga konsep tentang diri." Dalam perspektif, mata mewakili tubuh saat seseorang menerima suatu imaji, sehingga imaji menjadi sangat tergantung pada cara seseorang melihat dari titik tertentu. Penemuan ini memposisikan mata sebagai titik pusat, bukan hanya untuk dunia perseptual, tetapi juga membawa efek pada konsep diri. Representasi perspektival itu berubah menjadi simbolis, yakni sesuatu yang tidak hanya merumuskan, tetapi juga mengkondisikan persepsi.

Imaji akan berkeberatan (objects) bagi objektifikasi habitual manusia ini; ia tidak akan sepenuhnya memberikan dirinya sendiri, dan tidak akan seutuhnya mempersembahkan (yields) dirinya sendiri bagi birahi mata manusia. Bukti yang paling ekstrim hal ini, ialah ketika seseorang mencoba melakukan tatapan (staring) yang intensif, sebuah tatapan yang kaku pada sesuatu di hadapannya. Dalam teks-teks filsafat modern, vision sudah selalu dihadirkan-kembali oleh garis pandang lurus, fokus yang tajam, yang jelas mutlak, dan terpaku pada objeknya, sesuatu yang diposisikan di hadapannya. Demikianlah yang diamati David Michael Levin. ${ }^{72}$ Bila seseorang menatap sesuatu secara intensif, alih-alih mendapat persepsi yang jelas dan tegas, malah menjadi kabur dan membingungkan; alih-alih pemenuhan, mata kehilangan penglihatannya, dan terselaput air mata; alihalih stabilitas dan ketepatan di ujung tatapan, orang menemukan pergerakan yang khaotik, sentakan-sentakan tidak beraturan, seperti objek fokus yang secara semena-mena berlari-lari dari tahanan pandangan. Semakin intensif bergumul untuk menolak, menekan, atau memperlambat proses natural perubahan, semakin seseorang menolak menerima kefanaan, semakin ia memaksakan metafisika substansi yang senantiasa tersedia, semakin dengan keras dunia akan membuat terlihat self-destruction manusia.

Menatap menjadi usaha untuk mendominasi, tetapi, pada akhirnya, ia selalu mendorong seseorang untuk melihat secara spontan, lewat perubahan tidak terkontrol dalam bidang visualitas: perubahan yang terjadi, entah diinginkan atau tidak. Jika memusatkan mata pada ujung 
sebuah gedung dan bertahan untuk menatapnya, orang akan mendapati bahwa seluruh gedung mulai bergerak-gerak, bergeser dengan cara yang aneh dan "tidak natural". Demikian pula ketika menatap titik tertentu pada sebuah bukit yang jauh, bukit itu akan mulai merenggang, mulai berputarputar "tanpa-akhir" di sepanjang horizon. Bisa dibayangkan apa yang dilakukan bila seseorang menginginkan fokus yang jernih dan konsentrasi untuk mendapat pemahaman luas yang objektif, serta kesadaran yang tenang dan jernih. Orang menutup matanya, menutup organ filosofisnya, menghentikan organ oksosomatisnya, menurunkan ke titik terendah "indra termulia"nya. Hanya dengan cara demikian indra-indra yang lain diberi tempat, menjadi kemungkinan lain sumber-sumber kebenaran.

Tidak mungkin menutup mata selama film diputar. Persoalannya adalah bahwa cara pandang orang sudah terimbas okularsentrisme, dan ini menjadi tantangan tersendiri bagi para seniman untuk mengambil bagian dalam pembongkaran tendensi-tendensi okularsentrisme dalam budaya visual kini, membangun kembali kesadaran manusia kontemporer untuk merasakan sensasi kebenaran yang juga bisa dihadirkan bersamaan dengan indra-indra lain tanpa mengutamakan salah satu.

\section{Sebuah Iconic Turn}

Dalam film Darek Jarman, Blue, 'melihat' tidak selalu berarti 'menurut' pada sebuah index atau vocabulary tertentu dari apa yang disebut film. Bukan hanya event yang dipahami sebagai sesuatu yang terletak di balik sinema, tetapi film itu mengajak manusia untuk merumuskan ulang asumsiasumsinya tentang persepsi dan imaji, dan karenanya membebaskan dari asumsi-asumsi tertentu tentang imaji, membebaskan cara melihat dan memandang. Dengan mengaitkan indeksikalitas auratik imaji-imaji dalam film itu, 'rasa' yang dihasilkan ketika melihat dan mendengarkan jejak-jejak dan rekaman suara serta peristiwa yang ada di luar dan sebelum sebuah film tercipta. Imaji-imaji yang terlempar dari dalam film menjadikan film itu seperti sebuah doa yang memperdengarkan rintihan harapan kemanusiaan. Di titik ini muncul keterkejutan dan serentak penolakan representasinya dalam bahasa visual. Film ini tidak hanya membawa orang pada pertanyaan mendasar seperti "Imaji apa itu?", tetapi juga pada pertanyaan penting: "Sebuah imaji dapat menjadi apa?” Film Blue, dan juga 
film-film Jarman lainnya mengingatkan bahwa obsesi seseorang pada imaji sering secara implisit dimengerti dalam kerangka okularsentrisme yang mengacu pada "perumusan diri", jaringan-jaringan kekuatan, relasi etis, media di dalam ekonomi visual yang secara konseptual menjadi indentur antara 'kehidupan' dan imaji. Sebagai konsekuensinya, 'imaji' sebagai suatu kategori analisis resisten terhadap pemahaman teoretis.

Seperti dikatakan Jacques Ranciere dalam The Future of the Image, 'Imaji' mengacu pada hal-hal yang berbeda. Ada relasi sederhana yang menghasilkan keserupaan dari yang orisinal, bukan selalu salinan yang persis, tetapi hanya apa yang cukup membuatnya berdiri. Ada interplay operasi-operasi yang menghasilkan apa yang disebut sebagai seni, atau persisnya sebuah alterasi keserupaan." ${ }^{\text {73 }}$ Bagi Rancier, 'imaji' berarti sebuah proses inskripsi dan artikulasi yang senantiasa bergerak, yang secara mutual bertautan satu dengan yang lain. Misalnya, kata (sebagai imaji) bisa mengacu tidak hanya pada penglihatan dan persepsi visual, tetapi juga pada kapasitas moral tertentu, pemahaman dunia yang hidup, artikulatif, imajinatif, tentang kehidupan, tentang realitas, sebuah rasa mendalam dari apa yang sungguh-sungguh penting, realisasi yang jelas dari perhatian ultim seseorang, dan bagaimana dunia harus berelasi dengan perhatianperhatian ini, kapasitas untuk berpikir tentang hal-hal dengan rasa tentang bagaimana mereka semua bergantung bersama, tentang bagaimana segala sesuatu yang datang bersama untuk membentuk keseluruhan, keutuhan bukan totalitas, dan kapasitas untuk membayangkan sebuah dunia, kehidupan, realitas yang berbeda dan yang lebih baik.

Jean Paris pernah memberikan analisis yang menarik lukisan dinding di Basilika San Marco-Venice, The Pantocrator. Dilihat dari simetri frontal lukisan itu, orang akan mendapati informasi bahwa "Sinar visualNya, Pandangan-Nya" terproyeksikan tepat ke depan-Nya, tegak lurus ke dinding-dinding Basilika. Simetri ini, menurut Paris, adalah untuk "menegaskan Otoritas Yang Mahakuasa," karena ini adalah cara yang jelas untuk "menekankan vigilansi visual-Nya, kualitas tertinggi Sang Pengamat", sebuah "Pantepopte" (Kristus yang memandang ke semua arah, Christ the-all-seeing). ${ }^{74}$ Mozaik Byzantium ini mempersembahkan sebuah teologi tersendiri. Mungkin orang tidak akan menemukan ilusi 
kedalaman (depth) dalam imaji itu, dan bahwa imaji ini ada dalam sebuah ruang kudus dengan dinding-dinding emas yang bisa menjadi gangguan untuk menjadikan imaji ini 'milik' seseorang, namun ada batas-batas supranatural yang tersingkap, yang pada saat yang sama membatasi ketidakterbatasan absolut Sang Imaji. Paris menambahkan, “... namun jelas bahwa ada dimensi ketiga [depth] dalam mozaik [dua dimensi] ini dan kita tidak menemukannya pada latar belakang imaji itu, tetapi di depannya, menonjol lurus ke depan sebagai Yang Dipandang oleh Transendensi itu sendiri: kita adalah dimensi ketiganya, kita adalah gambarnya!"75

Paris menjelaskan bahwa relasi visual macam ini secara brilian menyelesaikan konflik teologis antara kebutuhan untuk menghadirkan Tuhan dan bahaya idolatri, dengan mengurangi dimensionalitas transendensi ilahi-Nya dalam sebuah objek-untuk-kita yang terlihat. Hasil yang sama juga bisa dilihat dalam teknik yang lain, misalnya, dalam lukisan The Hodigitria. Ada rotasi visual sederhana yang membawa implikasi revolusioner. Pertama, aksis simetri pandangan yang telah dihancurkan; kedua, frontalitas Maria dan Yesus memberi jalan untuk keragaman yang lebih memanusiawikan, postur yang lebih profan dan duniawi; ketiga, tatapan-tatapan kuat yang menaklukkan seseorang pada kekuatan misteriusnya, sekarang secara perlahan teralihkan, melihat ke tempat yang lain. ${ }^{76}$ Tatapan-tatapan yang ilahi menjadi tatapan kita; kita kembali menjadi imago-dei, ketika tatapan seseorang tidak lagi berupa tatapan egologi-narsistik, tetapi sebuah

"perspektif yang membuat saya melihat dunia sebagaimana Tuhan melihatnya. Kita bisa memahami pernyataan ini pada nilai wajahnya: ketika ruang menjadi perjalanan tak berujung dari mata kita, ketika setiap karakter, setiap bentuk, menemukan sebuah kesendirian yang tidak perperikan, ketika dunia tidak memiliki sesuatu untuk ditawarkan kecuali ketiadaan, lantas 'Pandangan' ilahi akan terbatasi sepenuhnya, sehingga lukisan (seperti juga literatur) membalikkan seluruh arahnya."’7

Visualitas seseorang akhirnya terarahkan pada yang-lain, mengundang mereka masuk kembali sebagai bagian dari Logos, himpunan imago-dei yang bersama-sama menanti sebuah Anunsiasi, kabar-gembira, tentang pulihnya relasi-relasi yang selama ini sudah sedemikian predatorik.

Dalam contoh-contoh di atas, diamati oleh Levin bahwa kebenaran tidaklah berarti 'ketepatan' (correctness), sebuah representasi memuaskan dari realitas, sebuah homoiosis antara logos dan pragma, sebuah adequatio intellectus et rei, sebuah kesepakatan, atau korespondensi antara pengetahuan 
dan objeknya. ${ }^{78}$ Teori ini secara inheren mengandaikan adanya asumsi bahwa pengalaman kebenaran adalah selalu dan perlu terstruktur dalam kerangka hubungan subjek-objek: kenyamanan representasi subjek pada keterberian objek yang terepresentasi. Mungkin kebenaran di sini adalah, dengan meminjam Heidegger, sebuah peristiwa, dan mengacu pada Mitchell, sebuah "uji coba" (truthing), sesuatu yang terjadi hanya bila ada keikhlasan dan keterbukaan. ${ }^{79}$ Ini menuntut orang untuk senantiasa terbuka pada apapun yang ada dalam horizon, menuntut kapasitas luar biasa untuk memperhatikan dan serentak berhati-hati memperlakukannya, yang di dalamnya kebenaran dirawat dan serentak ditangguhkan sementara, karena kebenaran pun ada dalam kedua akar kata kedua itu: hati.

Richard Rorty pernah mengamati evolusi dalam filsafat (barat) yang bergerak perhatiannya terhadap hal-hal atau objek, ide dan konsep, dan akhirnya (pada Abad ke 19) pada bahasa, yang dikenal sebagai linguistic turn. Terinspirasi hal itu, kini pusat perhatian secara khusus adalah pada imaji, sebuah "iconic turn" atau "pictorial turn". Namun, seperti diamati Mitchell, ini bukan seperti diartikan oleh Gottfried Boehm dalam disiplin akademik ketat-terbatas untuk melabeli kebangkitan dari apa yang disebut sebagai media visual (TV, video, sinema). ${ }^{80}$ Iconic turn lebih berupa dinamika membiarkan dan menyemarakkan imaji sebagai topik penting, baik dalam politik maupun budaya massa, serta juga dalam refleksi paling umum psikologi manusia dan perilaku sosial, dan dalam struktur pengetahuan. Wittgenstein menggambarkan bahwa filsafat di Abad ke-20 tidak hanya memunculkan lingustic turn, namun mesti menanggapi “imaji yang 'memerangkap' kita” dengan berbagai cara untuk mencari jalan keluar: semiotika, strukturalisme, dekonstruksi, teori sistem, sains imaji, ikonologi kritis, dan sebagainya." 81 Pelbagai cara pencarian jalan keluar ini niscaya melahirkan cara pembacaan yang baru terhadap filsafat, dan mungkin juga memulihkan cara melihat manusia menjadi lebih utuh.

Sampai di sini, imaji tidak dipandang sebagai totalitas, tetapi keutuhan. 'Utuh' secara esensial berbeda dari totalisasi 'totalitas'. Sebuah totalitas dapat ditundukkan, didominasi, dan dikontrol, dapat digenggam dan dimiliki, dapat dipastikan dan diamankan, dapat diketahui dengan kepastian, dan adalah sebuah keberselesaian yang absolut. Sebuah 'keutuhan' juga memiliki keberselesaian, tetapi keberselesaian yang terbuka. Sonata, lukisan, foto, percakapan, gestur, sunset, horizon—semua itu memiliki awal 
dan akhir, kesatuan tertentu, koherensi, dan selesai. Akan tetapi, keutuhan ini tidak menghambat keberlanjutan mereka, dan masing-masing tetap terbuka pada pengayaan dan perkembangan selanjutnya. Artinya, sebuah keberselesaian yang berbeda-beda.

\section{Bibliography:}

Didi-Huberman, Georges. Image in Spite of All: Four Photographs from Aushwit: Trans. Shane B. Lilis Chicago: University of Chicago Press, 2008.

Confronting Images: Questioning the Ends of a Certain History of Art. Trans. John Goodman. University Park: Pennsylvania State Press, 2005.

Epstein, Jean. "Magnification." French Film Theory and Criticism, A History/ Anthology, Vol I: 1907-1929. Ed. Richard Abel. Princeton: Princeton University Press, 1988.

Flammarion, Camille. Thunder and Lightning. Trans. Walter Mastyn. London: Chatto \& Windus, 1905.

Gibson, James J. The Perception of the Visual World. Boston: Houghton Mifflin Company, 1950.

Janus, Aderienne. "Listening: Jean-Luc Nancy and the "Anti-Ocular" Turn in Continental Philosophy and Critical Theory," Comparative Literature, Vol. 63. No. 2 (Spring 2011): 182-202.

Jay, Martin. Downcast Eyes: the Denigration of Vision in Twentieth-Century French Thought. California: University of California Press, 1994.

."The Rise of Hermeneutics and the Crisis of Ocularsentrism,"

Poetic Today, Vol. 9, No. 2, The Rhetoric of Interpretation and the Interpretation of Rhetoric (1988): 307-323.

Khalip, Jacques \& Robert Mitchell (Eds.). Releasing the Image: From Literature to New Media. California: Stanford University Press, 2011.

Levin, David Michael (Ed.). Modernity and the Hegemony of Vision. California: University of California Press, 1993. (Ed.). Sites of Vision: The Discursive Construction of Sight in the History of Philosophy. Cambridge Mass.: The MIT Press, 1997. 
The Opening of Vision: Nibilism and the Postmodern Situation. New York: Routledge, 1988.

McLuhan, Marshall. Understanding Media: The Extensions of Man. New York: McGraw-Hill, 1964.

- The Guttenberg Galaxy: The Making of Typographic Man.

Toronto: University of Toronto Press, 1962.

Mitchell, William John Thomas. Iconology: Image, Text, Ideology. Chicago: The University of Chicago Press, 1986.

- Image Science: Iconology, Visual Culture, and Media Aesthetics.

Chicago: The University of Chicago Press, 2015.

. What Do Picture Wants? Chicago, The University of Chicago

Press, 2005.

Ong, Walter. The Presence of the Word. New Haven: Yale University Press, 1967.

Pallasmaa, Juhani. The Eyes of the Skin: Architecture and the Senses. West Sussex-England: John Wiley \& Sons Ltd., 2008.

Panofsky, Erwin. Meaning in the Visual Art. New York: Anchor Doubleday, 1955.

Paris, Jean. Painting and Linguistic. Pittsburgh: Carnegie-Mallon University, 1975.

Ranciére, Jacques. The Future of the Image. Trans. Gregory Elliot. London: Verso, 2007.

Silverman, Kaja. World Spectators. Standford: Standford University Press, 2000.

Sloterdijk, Peter. Critique of Cynical Reason. Trans. Michael Eldfed. Minneapolis: University of Minnesota Press, 1987.

Sugiharto, Bambang (Ed.). Untuk. Apa Seni? Bandung: Pustaka Matahari, 2013. existence

\section{Endnotes:}

1 https://collider.com/martin-scorsese-says-marvel-movies-are-theme-parks-notcinema (access 17.11.2019).

2 Martin Scorsese, "Martin Scorsese: I Said Marvel Movies Aren't Cinema. Let Me Explain," The New York Times - Opinion; https://www.nytimes.com/2019/11/04/ opinion/martin-scorsese-marvel.html (access 17.11.2019).

3 Ibid. 
4 Ben Child, “'Of Course Marvel is Cinema!' Why the Scorsese Backlash is Justified”, The Gurardian Opinion; https://amp.theguardian.com/film/2019/oct/17/ofcourse-marvel-is-cinema-why-the-scorsese-backlash-is-justified-kevin-smith (access 17.11.2019).

5 Bambang Sugiharto, "Film dan Hakikatnya," Untuk Apa Seni?, ed. Bambang Sugiharto (Bandung: Matahari, 2013) 341.

6 Jean Epstein, "Magnification," French Film Theory and Criticism: A History/Anthology, Vol I: 1907-1929, ed. Richard Abel (Princeton: Princeton University Press, 1988) 240; cetak miring sesuai teks asli.

7 Germaine Dulac, "The Essence of the Cinema: The Visual Idea," The Avant-Garde Film: A Reader of Theory and Criticism, ed. P. Adams Sitney (New York: Anthology Film Archives, 1987) 41.

8 Stan Brakhage, Metaphors on Vision, ed. P. Adams Sitney (New York: Film Culture Inc., 1963) 120.

9 Sebagaimana Missale kini, bagian pengudusan ini dicetak dengan warna berbeda: hitam dan merah. Warna hitam dihasilkan dari tinta hitam yang merupakan percampuran dari pelbagai sari minyak tusam (turpentin) dan empat jenis minyak lainnya, sedangkan warna merah dihasilkan dari minyak merah yang merupakan perpaduan lebih sedikit minyak dengan tambahan Vermillion (pigmen merah terang yang diekstraksi dari kayu manis). Lih. Pierre Lemmy, sebagaimana dikutip Peter Geimer, "'Self-Generated' Image", Releasing the Image: From Literature to New Media, ed. Jacques Khalip \& Robert Mitchell (California: Stanford University Press, 2011) 34-35; untuk selanjutnya disingkat, Geimer, "'Self-Generated' Image".

10 G. E. Lessing membedakan seni berdasarkan bagaimana seni menjadi perantara "realitas yang terberikan" (the givenness of reality): seni yang berdasar pada waktu (time-based art) seperti puisi, sastra, dsj; dan seni yang mendasarkan pada ruang (space-based art) seperti lukisan, patung, dan lain-lain. Seorang pematung atau pelukis dibatasi merepresentasikan satu momen, dan karenanya harus memutuskan momen mana yang akan memberikan "kebebasan berimajinasi" (free rein to the imagination), yaitu momen yang "semakin kita lihat, semakin kita mampu berimajinasi". Konsekuensinya, pelukis/pematung tidak harus merepresentasikan klimat sebuah emosi (misalnya, teriakan aktual karena kesakitan yang nyata, karena ini justru akan memberikan kepada imajinasi semacam keterjangkauan dari apa yang ada di balik sesuatu yang hendak direpresentasikan.) Sebaliknya, seorang penyair atau pujangga tidak perlu "memadatkan gambar-gambarnya ke dalam sebuah momen tunggal", namun mendeskripsikan tindakan-tindakan yang mengulur-ulur sepanjang waktu, karena "proses suksesi waktu adalah wilayah penyair, sebagaimana ruang adalah wilayah si pelukis." Dua pembedaan seni ini menghasilkan secara fenomenal ragam imaji yang berbeda: sebuah lukisan menyediakan kepada penontonnya imaji yang harus diambil semua secara serentak, sementara puisi menciptakan rangkaian imajiimaji yang bermekaran di hadapan pembaca/pendengar. Lih. Jacques Khalip \& Robert Mitchell (eds.), Releasing the Image: From Literature to New Media, (California: Stanford University Press, 2011) 6-8; selanjutnya disingkat Khalip, Releasing the Image.

11 John Berger, Ways of Seeing (London: Penguin Books Ltd., 1972) 7; bdk. Geimer, "'Self-Generated' Image", 31-32.

12 Rudolf Arheim, "Photography - Being and Expression," sebagaimana dikutip oleh Geimer, art. cit., 36. 
13 Camille Flammarion, Thunder and Lightning, trans. Walter Mastyn (London: Chatto \& Windus, 1905) 26-69.

14 Geimer, "'Self-Generated' Image”, 36.

15 Ibid., 43.

16 Ibid.

17 Georges Didi-Huberman, Confronting Images: Questioning the Ends of a Certain History of Art, trans. John Goodman (University Park: Pennsylvania State Press, 2005) 190.

18 Georges Didi-Huberman, Image in Spite of All: Four Photographs from Aushwitr, trans. Shane B. Lilis (Chicago: University of Chicago Press) 70.

19 Geimer, "'Self-Generated' Image", 43.

20 Roland Barthes, Rhetoric of the Image, sebagaimana dikutip oleh Geimer, ibid., 30.

21 W. J. T. Mitchell, Image Science: Iconology, Visual Culture, and Media Aesthetics (Chicago: The University of Chicago Press, 2015) 16; selanjutnya disingkat Mitchell, Image Science.

22 W. J. T. Mitchell, Iconology: Image, Text, Ideology (Chicago: The University of Chicago Press, 1986) 10; selanjutnya disingkat Mitchell, Iconology.

23 Lih. ibid.

24 Ibid.

25 E. H. Gombrich, Art and Illusion: A Study in the Psychology of Pictorial Representation (London: Phaidon Press, 1984 [1960]), 116.

26 Ibid.

27 Mitchell, Iconology, 16.

28 Ibid.

29 Ibid.

30 Ibid., 31.

31 Ibid.

32 Erwin Panofsky, "Iconology and Iconography", Meaning in the Visual Art (New York: Anchor Doubleday, 1955) 29.

33 Donald McCallum, Maimonides' Guide for the Perplexed: Silence and Salvation (Oxon: Routledge, 2007) 86-108.

34 "Bentuk spesifik"-nya Maimonides harus dibedakan dari istilah 'spesies' Aristoteles yang menggunakannya dalam arti literal, material. 'Spesies' Aristotels adalah "bentuk artifisial"-nya Maimonides.

35 Mitchell, Iconology, 33.

36 Mitchell, Image Science, 84.

37 Mitchell, William John Thomas, What Do Picture Wants? (Chicago: The University of Chicago Press, 2005) 28-56.

38 Maurice Blanchot, The Space of Literature, trans. Ann Smock (Lincoln: University of Nebraska Press, 1999) 254-258.

39 Ibid.

40 Mitchell, Image Science, 67.

41 Ibid., 70. 
42 David Michael Levin (ed.), Modernity and the Hegemony of Vision (California: University of California Press, 1993) 287; selanjutnya disingkat Levin, Modernity and Hegemony.

43 Penelitian modern mencatat bahwa di antara kelima indra manusia, mata adalah yang paling aktif. Mata mengirim informasi ke otak 10 juta bit per detik, kulit mengirim 1 juta bit per detik, telinga dan penciuman sekitar 100 ribu bit per detik, dan perasa 1000 bit per detik. Indra penglihatan sejauh ini dipandang yang terkuat dari indraindra lain, yang mengirimkan sejumlah besar informasi ke otak manusia.

44 Martin Jay, Downcast Eyes: The Denigration of Vision in Twentieth-Century French Thought (California: University of California Press, 1994) 11; selanjutnya disingkat Jay, Downcast Eyes.

45 Marshall McLuhan, Understanding Media: The Extensions of Man (New York: McGraw-Hill, 1964) 5; bdk. Marshall McLuhan, The Guttenberg Galaxy: The Making of Typographic Man (Toronto: University of Toronto Press, 1962) 68.

46 Walter Ong, The Presence of the Word (New Haven: Yale University Press, 1967) 74.

47 Beberapa kata ini sudah disadari dalam penggunaan sehari-hari dengan sendirinya mengacu pada aktivitas melihat. Di sini hanya akan ditunjukan kata-kata yang tampak tidak lazim dihubungkan dengan acuan okular, misalnya, 'theater' (Yunani theasthai, 'behold'); 'theory' (Yunani theōros, 'spectator').

48 Kaja Silverman, World Spectators (Standford: Standford University Press, 2000) 25.

49 Jay, Downcast Eyes, 35.

50 Ibid., 12.

51 Peter Sloterdijk, Critique of Cynical Reason, trans. Michael Eldfed (Minneapolis: University of Minnesota Press, 1987) 145.

52 Jay, Downcast Eyes, loc. cit.

53 Ibid., 64.

54 Rene Descartes, Discourse of Method, Everyman's Library, ed. Ernest Rhys (London: J. M. Dent \& Sons Ltd., 1912) 28.

55 Bukti ontologis Descarters muncul dalam Meditasi Kelima, dalam kaitannya dengan eksistensi Tuhan dalam Meditasi Ketiga. Menurut Descartes, eksistensi Tuhan dibangun atas dasar fakta bahwa Descartes memiliki sebuah ide Tuhan yang jelas dan tegas (pembedaan yang jelas dan tegas antara Essence dan Existence); namun kebenaran ide yang jelas dan tegas itu dijamin oleh fakta bahwa Tuhan ada dan bukan seorang penipu. Dengan maksud menunjukkan bahwa Tuhan ada, Descartes harus mengasumsikan bahwa Tuhan itu ada.

56 David Michael Levin, The Opening of Vision: Nibilism and the Postmodern Situation (New York: Routledge, 1988) 3; selanjutnya disingkat Levin, The Opening of Vision.

57 Lih. ibid., 4.

58 Lih. ibid.

59 Lih. ibid., 66

60 Lih. ibid., 12.

61 Lih. ibid., 119.

62 Juhani Pallasmaa, The Eyes of the Skin: Architecture and the Senses (West Sussex-England: John Wiley \& Sons Ltd., 2008) 23; selanjutnya disingkat Pallasmaa, The Eyes of the Skin. 
63 Martin Jay, "The Rise of Hermeneutics and the Crisis of Ocularsentrism," Poetic Today, Vol. 9, No. 2, The Rhetoric of Interpretation and the Interpretation of Rhetoric (Duke University Press, 1988) 307-323; untuk selanjutnya disingkat Jay, "The Rise"

64 David Michael Levin (ed.), Sites of Vision: The Discursive Construction of Sight in the History of Philosophy (Cambridge Mass.: The MIT Press, 1997) 5.

65 Jay, "The Rise," 313.

66 Ibid., 316

67 Ibid.

68 Ibid.

69 Ibid., 317

70 Pallasmaa, The Eyes of the Skin, 11.

71 James J. Gibson, The Perception of the Visual World (Boston: Houghton Mifflin Company, 1950).

72 Levin, The Opening of Vision, 68.

73 Jacques Ranciére, The Future of the Image, trans. Gregory Elliot (London: Verso, 2007) 6.

74 Jean Paris, Painting and Linguistic (Pittsburgh: Carnegie-Mallon University, 1975) 3172.

75 Lih. ibid.

76 Lih. ibid.

77 Lih. ibid.

78 Levin, The Opening of Vision, 420. Homoiosis: sebuah pathology karena adanya transformasi bentuk tubuh; pragma: realitas konkret; adequatio intellectus et rei: "the intellect (of the knower) must be adequate to the thing (known)."

79 Mitchell, Image Science, 423.

80 Ibid., 14.

81 Ibid., 16. 